Василь Ягупов, доктор педагогічних наук, професор, Національний університет оборони України імені Івана Черняховського, м. Київ

ORCID ID 0000-0002-8956-3170

Сергій Жембровський, кандидат педагогічних наук, доцент, Національний університет оборони України імені Івана Черняховського, м. Київ

ORCID ID 0000-0003-4903-9398

DOI: $10.33099 / 2617-1775 / 2020-02 / 378-392$

\title{
ПЕРСПЕКТИВНА СИСТЕМА ДІАГНОСТУВАННЯ ФІЗИЧНОЇ ПІДГОТОВЛЕНОСТІ ВІЙСЬКОВОСЛУЖБОВЦІВ ЗБРОЙНИХ СИЛ УКРАЇНИ: ТЕОРЕТИКО-МЕТОДОЛОГІЧНЕ ОБГРУНТУВАННЯ
}

У статті представлено перспективну систему діагностування фізичної підготовленості військовослужбовців Збройних сил (далі - ЗС) Украӥни, щуо здійснено на провідних ідеях, положеннях $і$ принщипах суб'єктно-діяльнісного та контекстного методологічних підходів до оцінювання їх професійної підготовленості як суб’єктів військово-професійної діяльності. Наголошується на необхідності врахування у прочесі діагностування їх фізичної підготовленості вимог до посадового призначення кожного військовослужбовия як військового професіонала, а також безпосередньо враховувати ї̈ контекст - вид і рід військ, вимоги до посади.

Ключові слова: діагностування; фізична підготовленість військовослужбовців; фізична готовність військовослужбовців; суб'єктно-діяльнісний підхід; контекстний підхід; шкали.

Постановка проблеми. У сучасних умовах функціонування ЗС України i виконання ними бойових завдань щодо забезпечення територіальної цілісності держави фізична підготовленість і готовність військовослужбовців має забезпечуватися та дотримуватися на основі об'єктивної інформації, яка необхідна командирам (начальникам) для комплексного оцінювання бойової готовності військових підрозділів (частин) у цілому та за іiі складовими, зокрема. У зв'язку цим необхідним $\epsilon$ цілеспрямоване послідовне та систематичне діагностування результативності фізичної підготовленості військовослужбовців взагалі та окремих їх категорій, зокрема, шляхом оцінювання їx фізичного стану, який складається із сукупності взаємопов'язаних ознак - фізичної працездатності в різних ситуаціях повсякденної, навчально-бойової та найголовніше - бойової діяльності, що $\epsilon$ результатом їх фізичної підготовленості та фізичної готовності. Результати такого діагностування дають можливість командирам (начальникам) безпосередньо впливати на фізичний розвиток і вдосконалення різних категорій особового складу ЗС України.

Проте, будь-яке діагностичне дослідження пов'язане зі значними методологічними, організаційними, методичними, критеріальними та діагностичними труднощами щодо об'єктивного з'ясування фізичної 
працездатності військовослужбовців, оскільки вимагає вирішення таких завдань:

по-перше, чіткого виокремлення методології діагностування фізичної працездатності військовослужбовців;

по-друге, визначення предмета діагностичного дослідження - фізичної підготовленості та фізичної готовності військовослужбовців і з’ясування їх проявів, які, евентуально, будуть оцінюватися;

по-третє, опрацювання чітких критеріїв діагностування предмета дослідження - фізичної підготовленості та фізичної готовності військовослужбовців i виокремлення їх шкал, які будуть підлягати діагностуванню;

по-четверте, значних витрат часу та енергії від досліджуваних, а також використання дослідником сучасної різноманітної апаратури діагностування фізичної працездатності військовослужбовців;

по-п’яте, застосування надійних статистичних критеріїв для статистичного доведення отриманих емпіричних і експериментальних даних щодо результатів діагностування фізичної працездатності військовослужбовців, тобто їх фізичної підготовленості та фізичної готовності.

Така методологічно та теоретично обгрунтована та статистично опрацьована достовірна інформація про поточний фізичний стан особового складу необхідна всім командирам (начальникам), які ухвалюють управлінські рішення в повсякденних, навчальних та особливо в навчально-бойових i бойових умовах. Така оперативна, надійна та об'єктивна інформація дає їм можливість, з одного боку, прогнозувати результати виконання поставлених перед військовим підрозділом (частиною) бойових завдань 3 урахуванням фізичного стану особового складу, а з іншого - виявляти сильні та слабкі сторони фізичної підготовленості особового складу та визначати конкретні заходи з метою подальшої іiі корекції, вдосконалення, а в певних ситуаціях й усунення. Це може бути необхідно як у межах повсякденної, навчально-бойової та бойової діяльності військ, так i для відбору найбільш підготовлених військовослужбовців для виконання окремих бойових завдань.

Аналіз останніх досліджень і публікацій. У процесі обгрунтування методологічних, організаційних, методичних, критеріальних і діагностичних аспектів щодо об'єктивного діагностування фізичної працездатності військовослужбовців суттєвий інтерес представляють наукові праці 3 таких проблем:

безперервної професійної освіти (С. Батишєв, Л. Лук'янова, Н. Ничкало, В. Радкевич та ін.);

- компетентнісного підходу у професійній освіті (В. Луговой, Дж. Равен, В. Свистун, В. Ягупов та ін.);

- розвитку професійної компетентності фахівців з фізичного виховання (О. Завальнюк, Л. Шевчук, Б. Лосін);

- окремих аспектів педагогічної діяльності викладачів фізичної культури (Т. Баєва, А. Дикунов); 
- фахової компетентності офіцерів ЗС України (О. Рибчук, О. Тракалюк), у тому числі начальників фізичної підготовки та спорту військових частин (Д. Погребняк, О. Чернявським, Ю. Сергієнко та ін.).

Різні аспекти вдосконаленню професійної підготовки фахівців у сфері фізичної культури і спорту досліджували В. Бальсевич, Л. Волков, Г. Грибан, Є. Ільїн, Ю. Желєзняк, Р. Карпюк, Т. Круцевич, Л. Матвєєв, О. Петрачков, С. Романчук, Л. Сущенко, Ж. Холодов, С. Хазова, Б. Шиян та ін.

Проблема діагностування в фізичній підготовці та спорту в ЗС України $\epsilon$ предметом дослідження А. Балдецького, Н. Вербина, С. Глазунова, С. Жембровського, В. Леонтьєва, А. Одерова, О. Петрачкова, Д. Погребняка, С. Романчука, С. Костіва, І. Шлямара, Г. Фіногенова, В. Ягупова та ін.

Військові науковці до основних недоліків наявної системи перевірки й оцінювання фізичної підготовленості військовослужбовців ЗС України відносять такі:

- наявність суворо визначених нормативів, тобто нормативний підхід до оцінювання фізичної підготовленості ставить військовослужбовців у жорсткі «рамки», не стимулює їх фізичне вдосконалення, зводить фізичну підготовку до виконання лише певних нормативів, не надає можливості для об'єктивного їх оцінювання справжнього рівня фізичної підготовленості кожного окремого військовослужбовця [2];

- «вимушена підпорядкованість» підсумкової оцінки 3 фізичної підготовленості військового підрозділу рівню фізичної підготовленості його окремих військовослужбовців, тобто коли в підрозділі є, наприклад, один офіцер, який при перевірці отримав незадовільну оцінку, то загальна оцінка військовому підрозділу знижується 3 «добре» до «незадовільно» [10];

- невідповідність рівня фізичної підготовленості військового підрозділу дійсному рівню, оскільки тї загальна оцінка визначається не від загальної кількості його військовослужбовців, який перевіряється, а від кількості перевірених військовослужбовців [4].

Певні недоліки в цьому аспекті також маються у системі вищої військової освіти. Науковці вказують на такі недоліки:

- зрівнювання нормативів для курсантів різних курсів набуття військовопрофесійної освіти у військових навчальних закладах (індивідуальна оцінка фізичної підготовленості зрівнює військовослужбовців, які мають зовсім різний рівень фізичної підготовленості [7];

- оцінювання рівнів розвиненості загальної фізичної підготовленості курсантів упродовж набуття вищої військово-професійної освіти у ВВНЗ $[8,109-110]$.

Разом із тим, проведений теоретичний аналіз результатів наукових досліджень та їх узагальнення показує, що проблема діагностування в фізичній підготовці та спорту в ЗС України, визначення критеріїв i показників діагностування конкретних фізичних якостей і станів військовослужбовців, у тому числі й єдині вимоги щодо здійснення перевірки та оцінювання рівнів фізичної підготовленості (готовності) військовослужбовців і фізичної 
підготовленості підрозділів (військових частин, ВВНЗ) до нині не знайшла достатнього наукового розв'язання.

Мета статті: обгрунтування методологічних, організаційних, методичних, критеріальних і діагностичних аспектів щодо об'єктивного діагностування фізичної працездатності військовослужбовців.

Методика дослідження. У процесі наукового пошуку застосовувався комплекс теоретичних i емпіричних методів дослідження. Використано такі теоретичні методи, як аналіз дисертацій, статей, матеріалів наукових конференцій, психолого-педагогічної, методичної, спеціальної літератури 3 проблеми дослідження. 3 емпіричних методів застосовувалося бесіди 3 викладачами, слухачами, фахівцями в галузі фізичної підготовки та спорту. Дослідження виконувалося в Інституті фізичної культури та спортивнооздоровчих технологій Національного університету оборони України імені Івана Черняховського.

Виклад основного матеріалу. Своєчасне об’єктивне діагностування фізичної підготовленості військовослужбовців, інтегрованим проявом якої $є$ їх фізична працездатність у різних умовах військово-професійної діяльності, $\epsilon$ однією 3 проявів управлінської та діагностичної функцій командирів (начальників) усіх ланок управління, важливим елементом організації бойової підготовки військових підрозділів і частин взагалі та фізичної підготовки військовослужбовців різних категорій, зокрема. Методологічно обгрунтована організація такого діагностування дозволяє системно, комплексно, контекстно й всебічно з'ясувати та оцінювати фізичний стан і фізичну підготовленість військовослужбовців, проаналізувати динаміку їх змін за певний проміжок часу, вивчити позитивний досвід навчання і виховання військовослужбовців у процесі фізичної підготовки, виявити певні недоліки та комплексно напрацювати заходи щодо їх усунення, а також подальшого підвищення фізичної підготовленості різних категорій військовослужбовців.

Для об'єктивного діагностування фізичної працездатності військовослужбовців насамперед необхідно чітко з'ясувати методологічні, організаційні та методичні його аспекти, інтегрованим проявом яких є критерії і показники оцінювання фізичної працездатності військовослужбовців.

Насамперед слід з'ясувати провідні ідеї на положення, на які будуть спиратися діагностичні дослідження у фізичній підготовці та спорті в 3С України. У зв'язку 3 цим, що це один із різновидностей діяльності військовослужбовців, то обов'язково має бути діяльнісний аспект під конкретного військового фахівця, тобто оцінювання фізичної працездатності військовослужбовців має бути, з одного боку, згідно зі вимогами військовопрофесійної діяльності, а з іншого - до конкретного фахівця, тобто конкретного суб'єкта військово-професійної діяльності з урахуванням виду та роду військ, посади, яку обіймає конкретний військовослужбовець. Такий підхід визначається нами як «суб'єктно-діяльнісний» [15], провідні методологічні положення якого представлені в наукових роботах С. Рубінштейна, К. Абульханової-Славської, А. Брушлинського, І. Зязюна, В. Петровського, В. Татенка, В. Ягупова та ін. Для нас важливою є думка С. Рубінштейна, який 
наголошував, що особистість стає суб'єктом, коли вона $є$ центром самоорганізації, саморегуляції та самоактуалізації [1], тобто мають бути всі ці аспекті в оцінці фізичної підготовленості військовослужбовців.

Отже, на основі узагальнення наукових напрацювань провідних науковців 3 проблеми суб'єкта та суб'єктності різних фахівців в якості основних характеристик суб'єкта діяльності можна виокремити такі суб'єктні прояви військовослужбовців у фізичній підготовці та спорті:

- активність у діяльності, а в нашому дослідженні - активність у фізичній підготовці та спорті військовослужбовців;

- самодетермінацію діяльності - самодетермінація військовослужбовців у фізичній підготовці та спорті;

- самоорганізацію діяльності - самоорганізація військовослужбовців у фізичній підготовці та спорті;

- рефлексивність військовослужбовців - об’єктивне самооцінювання та самосприйняття ними результатів своєї фізичної підготовки та спортивної підготовленості;

- самостійність у діяльності - самостійність військовослужбовців у фізичній підготовці та спорті;

- відповідальність за результати діяльності - відповідальність військовослужбовців за свої результати у фізичній підготовці та спорті;

- автономність у діяльності - автономність військовослужбовців у фізичній підготовці та спорті.

Отже, у зміст поняття «суб'єкт» щодо військовослужбовця вкладається «...активний початок людини в їі життєдіяльності, коли людина виступає не як «пасивна» істота, що залежна від зовнішніх умов і вимог ситуації, а як автор, ініціатор і режисер своєї активності, якій в процесі розвитку стало доступним опанування умов, що його оточують, і вимог, що висуваються оточенням. Відповідно з опануванням цих умов і вимог, людина вибудовує свою поведінку: десь реактивна та імпульсивна (в якій майже не проявляються піi якості як суб'єкта), а десь нею проектована, діяльна, що вибудовується за їі задумом» $[12,140]$, тобто як творчого суб'єкта військово-професійної діяльності.

Суб'єктом є кожен військовослужбовець, який усвідомлює реальність і свою індивідуальність і спосіб співіснування цих елементів у соціальному та військово-професійному середовищі. А професійна суб'єктність військовослужбовця є явищем почуттєвим, переконанням і досвідом життєвого та професійного буття конкретної особистості та військового фахівця, а в нашому випадку - військового професіонала відповідно, бути в повному смислі слова суб'єктом військово-професійної діяльності - це, насамперед, означає усвідомлювати власну роль, власну участь у ній і відповідальність за результати своєї діяльності. Почуття професійної суб'єктності - це переконання, що військовослужбовець є суб'єктом взаємин із військовопрофесійним та іншими сферами соціального середовища в суспільстві.

Виокремлюємо такі провідні характеристики професійної суб'єктності військових фахівців:

- ціннісна вмотивованість дій, вчинків, поведінки та в цілому діяльності, 
що демонструє причинну зумовленість військово-професійної діяльності;

- активність, яка відображає здатність фахівця як суб'єкта професійної діяльності до усвідомлених цілеспрямованих дій для досягнення поставлених цілей військово-професійної діяльності;

- здатність до рефлексії i, найголовніше - до саморефлексії у військовопрофесійній діяльності;

- усвідомлена модальність, що проявляється у розумінні військовими фахівцями як суб'єктами військово-професійної діяльності своїх особистісних, професійних і суб' єктних особливостей у порівнянні з іншими фахівцями;

- варіативність, що характеризує можливості фахівця свідомо обирати засоби військово-професійної діяльності [16, 325].

Відповідно, слід діагностувати професійного суб'єкта військовослужбовця та його фізичну підготовленість до конкретного виду військово-професійної діяльності. Окремі аспекти військовослужбовців як суб'єктів військової діяльності розкритті в наукових напрацюваннях О. С. Капінуса [5], В. Г. Кущова [6], В. І. Осьодла [9], І. В. Сиромятникова [11], В. В. Ягупова [17]. В їх працях містяться теоретико-методологічні підвалини діагностування професійного суб'єкта - військовослужбовця, які можна творчо адаптувати до діагностування фізичної підготовленості військовослужбовців.

У процесі діагностування фізичної підготовленості військовослужбовців слід актуалізувати такі прояви їх професійної суб'єктності як військових професіоналів:

- самооцінювання: усвідомлення військовослужбовцями особистісного, інтелектуального та професійного видів потенціалу як суб’єктів військовопрофесійної діяльності та визначення стратегії, тактики, методики та засобів їх актуалізації та реалізації за допомогою свого фізичного потенціалу та фізичної підготовленості;

- самопізнання: рефлексія і саморефлексія результатів самооцінювання своєї фізичної підготовленості, усвідомлення своїх фізичних якостей і фізичної підготовленості як суб'єкта військово-професійної діяльності;

- самоствердження: усвідомлення себе спочатку як фізичного підготовленого військовослужбовця та актуалізація своєї професійної суб’єктності за допомогою фізичної підготовленості та фізичних якостей;

- самодетермінація: стимулювання військовослужбовцем власного професійного становлення, розвитку та саморозвитку за допомогою фізичної підготовленості та професійно важливих фізичних якостей;

- саморегуляція - управління власною військово-прикладною фізичною підготовкою 3 урахуванням вимог нормативних та інших документів до фізичної підготовленості як військового професіонала, а також як фахівця окремого напряму військово-професійної діяльності;

- самореалізація - виявлення, розкриття та реалізація своїх фізичних потенційних можливостей і здібностей як військового професіонала;

- самоактуалізація - використання військовослужбовцем потенційних та актуальних фізичних можливостей i здатностей у військово-професійній діяльності як їі суб'єкта. 
Для оцінювання потенційних та актуальних фізичних можливостей i здатностей військовослужбовця як військового професіонала необхідно мати систему якісних і кількісних критеріїв їх діагностування, маючи на увагу той факт, що критерії є складними за змістом і структурою, являють собою сукупність певних показників діагностування розвиненості досліджуваних якостей, знань, навичок, умінь і в цілому у нашому випадку фізичної підготовленості, тобто вони мають бути контекстними - враховувати посадове призначення і вимоги посади до конкретного військовослужбовця. Теоретикометодологічні основи контекстного підходу до підготовки фахівців обгрунтовували С. Виготський і С. Рубінштейн та ін., а науковці контекстний підхід - у таких напрямах: концептуальні аспекти контекстного підходу (А. Вербицький, . Калашников, Н. Лаврентьєва, М. Левківський), використання потенціалу контекстного підходу до організації навчальновиховного процесу (А. Воронін, Ю. Калугін, О. Ковтун, В. Кругліков та ін.), контекстний підхід у підготовці фахівців (Н. Бакшаєва, О. Срмакова, І. Жукова, С. Качалова, С. Скворцова, О. Хомік та ін.). На основі узагальнення їх наукових напрацювань можна 3'ясувати, що на основі контекстного підходу динамічно моделюються предметний i соціальний зміст професійної діяльності конкретних фахівців, що забезпечує умови трансформації, на їх думку, навчальної діяльності тих, хто вчиться, у професійну діяльність спеціаліста, а використання контекстного підходу сприяє актуалізації інтелектуального i духовного видів потенціалу, «розвитку та саморозвитку фахівця» [14].

Як зазначає автор i розробник технології використання контекстного підходу в освіті А. Вербицький, теоретичними джерелами контекстного навчання $\epsilon$ поняття «контекст» як умова усвідомлення впливу змісту майбутньої професійної діяльності того, хто набуває професійну освіту, на процес і результати його навчальної діяльності $[3,183]$, а дефініція поняття «контекст» відповідно виступає змістостворювальною категорією щодо оцінювання фізичної підготовленості військовослужбовців.

Розв'язання проблеми оцінювання їх фізичної підготовленості на основі використання суб'єктно-діяльнісного та контекстного підходів до діагностування фізичної підготовленості військовослужбовців відкриває нові можливості і перспективи для більш і системного та контекстного їх пізнання як природної (біологічної), суспільної та найголовніше - військово-професійної істоти, розуміння і розвитку їх внутрішнього психічного світу, розкриття його творчого потенціалу та активної актуалізації в військово-професійній діяльності.

У навчально-науковому інституті фізичної культури та спортивнооздоровчих технологій Національного університету оборони України імені Івана Черняховського спільно 3 відділом фізичної підготовки управління доктрин та індивідуальної підготовки Головного управління доктрин та підготовки Генерального штабу Збройних Сил України розроблено та проведено з урахуванням вимог вищеперерахованих методологічних підходів апробацію перспективної системи функціонування фізичної підготовки у Збройних Силах України, в основу якої покладено єдині вимоги щодо 
діагностування рівнів фізичної підготовленості (готовності) військовослужбовців і фізичної підготовленості військових підрозділів (частин, BВHЗ).

Так Тимчасова настанова $з$ фізичної підготовки в Збройних Силах України визначає мету фізичної підготовки військовослужбовців наступним чином: забезпечувати фізичну готовність військовослужбовців до навчально-бойової діяльності [13]. Таке визначення $\epsilon$ не коректним, оскільки військовослужбовці мають бути готові не до навчально-бойової діяльності, а до бойової, оскільки у цьому полягає призначення ЗС України.

Фізична підготовка військовослужбовців розділяється на два види загальну та спеціальну.

Загальна фізична підготовка військовослужбовців спрямована на досягнення оптимального рівня розвиненості загальних фізичних якостей для подальшого успішного оволодіння ними спеціальними фізичними якостями $\mathrm{i}$ військово-прикладними навичками та вміннями, покращення якості фізичної розвиненості, зміцнення здоров'я шляхом систематичного виконання вправ із гімнастики, легкої атлетики, плавання, лижної підготовки та спортивних ігор.

Іїі завданнями такі:

- розвиток і вдосконалення фізичних якостей Сили, витривалості, швидкості та спритності;

- покращення якості їх фізичної розвиненості, зміцнення здоров'я, підвищення працездатності та службової активності;

- забезпечення професійного довголіття та стійкості організму до несприятливих чинників навколишнього середовища та військово-професійної діяльності, зменшення працевтрат, які пов'язані із захворюваннями.

Загальна фізична підготовка військовослужбовців сприяє вирішенню таких завдань:

- підвищенню якості їх військово-спеціальної підготовленості;

- веденню ними здорового способу життя;

- профілактиці захворюванням i фізичній реабілітації військовослужбовців;

- прискоренню їх адаптації до загальних і специфічних умов військової служби та військово-професійної діяльності;

- організації змістовного їх дозвілля та відпочинку.

Спеціальна фізична підготовка військовослужбовців спрямована на розвиток спеціальних фізичних якостей, оволодіння ними військовоприкладними навичками та вміннями, виховання професійних моральновольових якостей, досягнення бойової згуртованості військових підрозділів, шляхом систематичного комплексного виконання спеціальних фізичних i прикладних вправ 3 атлетичної підготовки, прискореного пересування, подолання перешкод, прийомів рукопашного бою, військово-прикладного плавання. Її завдання визначаються цілями, завданнями, засобами та специфікою військово-професійної діяльності військовослужбовців коректних видів ЗС України, родів військ і спеціальних військ.

До них можна віднести такі: 
- розвиток і вдосконалення спеціальних фізичних якостей: стійкості до заколихування; стійкості до перевантажень; стійкості до кисневого голодування;

- оволодіння та вдосконалення військово-прикладних рухових навичок, умінь, а в ідеалі - здатностей;

- виховання спеціальних морально-вольових i психічних якостей, необхідних військовослужбовцям;

- згуртування військових підрозділів.

Відповідно метою фізичної підготовки всіх категорій військовослужбовців 3С України $\epsilon$, на нашу думку, забезпечення фізичної підготовленості та готовності військовослужбовців до військово-професійної діяльності в найрізноманітніших та найголовніше - в екстремальних умовах бойової діяльності.

Фізична готовність - це, згідно зі [13], ступінь оволодіння встановленими стандартами фізичної підготовки, які забезпечують здатність військовослужбовців ефективно виконувати завдання за призначенням відповідно до займаних посад (військових спеціальностей). Фізична готовність $\epsilon$ обов'язком для військовослужбовців. Підтримання постійної фізичної готовності досягається систематичними фізичними тренуваннями, застосовуючи визначені засоби, форми і методи фізичної підготовки, а фізична підготовленість - це визначений навчальними нормативами рівень розвиненості загальних і спеціальних фізичних якостей, володіння військово-прикладними навичками та вміннями, що характеризує функціональний $\mathrm{i}$ моральнопсихологічний стан військовослужбовців.

Відповідно, для їх вимірювання необхідні загальні єдині тести, які мають включати в себе, на нашу думку, виконання військовослужбовцями таких фізичних вправ:

- 3 підтягування на перекладині - для визначення їх Силових якостей;

- човникового бігу 10x10 метрів - для 3'ясування їх швидкіснокоординаційних якостей;

- бігу на 3000 метрів - для визначення витривалості.

Тест - призначений для визначення рівня загальної фізичної підготовленості всіх військовослужбовців Збройних Сил України кандидатами вступу у ВВНЗ та військово-навчальні ЗВО, служби у військовому резерві, при розгляді атестаційних комісій при призначенні військовослужбовців на посаду без урахування вікових груп i гендерних особливостей (статі). Тест виконується протягом одного дня наприкінці занять у системі індивідуальної підготовки (один раз на рік). При застосуванні тесту доцільно враховувати категорій військовослужбовців відповідно до займаних посад, особливостей військово-професійної діяльності - 3 категорії.

У процесі розроблення системи нарахування балів за виконання фізичних вправ тесту (100 балів) передбачати зниження нормативів і доступність виконання їх мінімальних вимог (60 балів) за виконання кожної з вправ. При цьому встановлюється мінімальна сума балів за виконання 3-х вправ для різних категорій військовослужбовців, кандидатів для навчання, служби у резерві. 
Для військовослужбовців, які мають відхилення у стані здоров'я чи звільненні від виконання однієї із вправ за медичними показниками, доцільно передбачати виконання альтернативних вправ, тобто розробити відповідну систему нарахування балів і передбачати можливості оцінювання за двома чи однією вправою.

Водночас доцільно розробити єдині вимоги для визначення рівнів фізичної готовності військовослужбовців за тестом фізичної готовності. При цьому слід передбачати оцінювання за визначеним тестом один раз на рік упродовж останнього місяця етапу колективної підготовки підрозділів (2-3 дні) 3 урахуванням особливостей їх бойового призначення.

Перелік фізичних вправ тесту доцільно включити обов'язкові та вибіркові вправи, які в найбільшій ступені відповідають специфіці прийомів і дій, які виконують військовослужбовці у процесі виконання службових завдань за призначенням; наприклад, військовослужбовців категорії I (першої) з високими вимогами до рівня фізичної готовності, складається з 5 (п'яти) вправ:

- 2 (дві) обов'язкові вправи марш-кидок на 5 км і метання гранати на дальність і точність;

- 2 (дві) вибіркові вправи військово-прикладної чи спеціальної спрямованості з програми фізичної підготовки виду чи роду військ і Сил;

- виконання 1 (одного) відповідного стандарту фізичної підготовки виду (роду) військ, Сил;

б) для військовослужбовців категорії II (другої) з середніми вимогами до рівня фізичної готовності складається 34 (чотирьох) вправ:

- 2 (дві) обов'язкові вправи марш-кидок на 5 км і метання гранати на дальність і точність;

- 1 (одна) вибіркова вправа військово-прикладної чи спеціальної спрямованості з програми фізичної підготовки виду чи роду військ і Сил;

- виконання 1 (одного) відповідного стандарту фізичної підготовки виду (роду) військ і Сил;

в) для військовослужбовців категорії III (третьої) з низькими вимогами до рівня фізичної готовності складається 33 (трьох) вправ єдиного тесту фізичної підготовленості за умови збільшення загальної суми набраних балів.

Оцінка військовослужбовцю за кожною з вправ тесту фізичної готовності визначається як «виконав» чи «не виконав», відповідно до визначених нормативів. У разі виконання вправ у складі військового підрозділу оцінка кожному із військовослужбовців визначається на рівні його оцінки.

Загальна оцінка військовослужбовця тесту фізичної готовності визначається як «готовий», якщо виконано всі призначені для перевірки вправи, та «не готовий».

3 урахуванням специфіки військово-професійної діяльності військовослужбовці I та II категорій льотного та корабельного складу військовослужбовців, при визначені переліку обов'язкових вправ тесту фізичної готовності передбачати можливість їх коригування.

Курсанти ВВНЗ, військових навчальних підрозділів ЗВО, навчальних центрах (за ступенем вищої освіти «бакалавр», «магістр») у процесі проведення 
екзаменаційної сесії оцінюються відповідно до програми навчальної дисципліни та обов'язково 2 (два) рази за тестом фізичної підготовленості та 2 (два) рази за тестом фізичної готовності у період усього набуття вищої військово-професійної освіти.

Слухачі лідерських курсів і курсанти навчальних центрів 2 (два) рази за тестом фізичної підготовленості (попередній та підсумковий контролі) за нормативами, які відповідають відповідній категорії посад за якими здійснюється їх підготовка.

Загальну оцінку військовому підрозділу за виконання рекомендується виставляти так:

- тесту фізичної підготовленості: визначається за чотирьохбальною шкалою із врахуванням відсотку позитивних індивідуальних оцінок підрозділу.

У процесі визначення загальної оцінки за виконання кожного із тестів також доцільно здійснювати оцінювання якості керівництва, організації, забезпечення та проведення фізичної підготовки в підрозділі з визначенням оцінки: «відповідає встановленим вимогам» чи «не відповідає встановленим вимогам». Дана оцінка не впливає на загальну оцінку фізичної підготовки підрозділу, але враховується при аналізі їі стану та наданні пропозицій.

\section{Висновки:}

1. Обгрунтовано перспективну систему діагностування фізичної підготовленості військовослужбовців 3С України, що здійснено на провідних ідеях, положеннях i принципах суб'єктно-діяльнісного та контекстного методологічних підходів до оцінювання їх професійної підготовленості як суб’ єктів військово-професійної діяльності.

2. Доведено необхідність урахування у процесі діагностування їх фізичної підготовленості вимог до посадового призначення кожного військовослужбовця як військового професіонала та безпосередній контекст його військово-службової діяльності - вид і рід військ, вимоги до посади.

3'ясовано, що предметом діагностування $\epsilon$ фізична підготовленість i фізична готовність військовослужбовців, які мають відповідні шкали.

\section{ЛІТЕРАТУРА}

1. Абульханова-Славская К. А. Принцип субъекта в философско-психологической концепции С. Л. Рубинштейна. Философия России второй половиньл ХХ века. Москва : Российская политическая энциклопедия (РОССПЭН), 2010. С. 77-118.

2. Бородин Ю. А. Эффективность физической подготовки в системе военнопрофессионального обучения и пути ее повышения. Педагогіка, психологія та медикобіологічні проблеми фізичного виховання і спорту. 2003. № 10. С. 62-63.

3. Вербицкий А. А. Категория «контекст» в психологии и педагогике : монография. Москва : Логос, 2010. 300 с.

4. Глазунов С. I. Експрес-контроль спеціальної фізичної підготовленості військовослужбовців механізованих підрозділів сухопутних військ : автореф. дис. ... канд. наук з фіз. виховання і спорту : 24.00.02. Київ, 2003. 20 с.

5. Капінус О.С. Методологія, теорія і методика формування професійної суб'єктності майбутніх офіцерів Збройних Сил України : монографія. Житомир, 2020. 415 с. 
6. Кущов В. Г., Ягупов В. В. Концептуальні основи розвитку професійної суб'єктності у майбутніх фахівців розвідувальної діяльності в системі післядипломної освіти. Військова освіта. 2008. № 21. C. 3-12.

7. Леонтьев В. П. Нормативное обеспечение физической подготовки курсантов высших военно-учебных заведений Сухопутных войск Министерства обороны Украины : автореф. дис. ... канд. наук з фіз. виховання і спорту : 24.00.02. Київ, 2000. 22 с.

8. Одеров А., Шлямар I., Балдецький А. Система перевірки та оцінювання фізичної підготовленості військовослужбовців збройних сил іноземних держав. Молода спортивна наука України. 2013. Вип. 17. Т. 2. С. 109-113.

9. Осьодло В. І. Психологічні засади професійного становлення суб'єкта військовопрофесійної діяльності : дис. ...докт. псих. наук : 19.00.01. Київ, 2013. 554 с.

10. Романчук С., Романчук В. Фізична підготовка в сухопутних військах збройних сил провідних держав НАТО. Молода спортивна наука України. 2010. Вип. 14. Т. 2. С. 302-306.

11. Сыромятников И. В. Профессиональная субъектность офицера: сущность, структура и типологические проявления. Вестник Военного университета. 2007. № 2 (10). C. $50-58$.

12. Брушлинский А. В. Человек, субъект, личность в современной психологии : матер. междунар. конф. Москва, 2013. Т. 1. 584 с.

13. Про затвердження Тимчасова настанова з фізичної підготовки у Збройних Силах України: наказ Генерального штабу Збройних Сил України від 11.02.2014 p. № 35. Київ : ГШ ЗСУ, 2014. $158 \mathrm{c}$.

14. Ягупов В. В. Професійний розвиток особистості фахівця: поняття, зміст та особливості. Педагогічні, психологічні науки та соціальна робота. 2015. Т. 175. С. 22-28. URL: http://nbuv.gov.ua/UJRN/NaUKMApp_2015_175_4.

15. Ягупов В. В. Суб'єктно-діяльнісний підхід як ефективна методологічна основа формування готовності військового керівника до управлінської діяльності. Проблеми та перспективи формування національної гуманітарно-технічної еліти. 2008. Вип. 17 (21). C. 101-111.

16. Ягупов В. В. Субъектность и профессиональная субъектность педагога как интегральный показатель сформированности его профессиональной компетентности. Розвиток сучасної освіти: теорія, практика, інновації : зб. матеріалів II міжнар. наук.-практ. конф. (м. Київ, 25-26 лют. 2016 р.). Київ : Міленіум, 2016. С. 324-325.

17. Ягупов В. В., Крышталь Н. А., Король В. Н. Формирование и развитие профессиональной субъектности офицеров. Известия Российской академии образования. 2013. № 1. C. 74-83.

\section{REFERENCES}

1. Abul’xanova-Slavskaya, K. A. (2010). Pry`ncy`p subyekta v fy`losofskopsy`xology`cheskoj koncepcy`y` S. L. Ruby`nshtejna [The principle of the subject in the philosophical and psychological concept of S. L. Rubinstein]. Filosofiya Rossii vtoroy poloviny XX veka. Moskva : Rossiyskaya politicheskaya entsiklopediya (ROSSPEN), 77-118.

2. Borodyn, Yu. A. (2003). Effektivnost' fizicheskoy podgotovki v sisteme voyennoprofessional'nogo obucheniya i puti yeye povysheniya [The effectiveness of physical training in the system of military vocational training and ways to improve it]. Pedagogika, psy xologiya ta medy ko-biologichni problemy`fizy`chnogo vy`xovannya i sportu, 10, 62-63.

3. Verbitskiy, A. A. (2010). Kategoriya "kontekst" v psikhologii i pedagogike [Category "context" in psychology and pedagogy] (Monograph). Moskva: Logos, 300.

4. Glazunov, S. I. (2003). Ekspres-kontrol` special`noyi fizy`chnoyi pidgotovlenosti vijs`kovosluzhbovciv mexanizovany`x pidrozdiliv suxoputnyx vijs`k [Express control of special physical training of servicemen of mechanized units of the ground forces] (Abctract of $\mathrm{PhD}$ thesis). Kyiv, 20. 
5. Kapinus, O. S. (2020). Metodolohiya, teoriya i metodyka formuvannya profesiynoyi subyektnosti maybutnikh ofitseriv Zbroynykh Syl Ukrayiny [Methodology, theory and methods of forming the professional subjectivity of future officers of the Armed Forces of Ukraine] (Monograph). Zhytomyr, 415.

6. Kushhov, V. G., Yagupov, V. V. (2008). Kontseptualni osnovy rozvytku profesiynoyi subyektnosti u maybutnikh fakhivtsiv rozviduvalnoyi diyalnosti $\mathrm{v}$ systemi pislyadyplomnoyi osvity [Conceptual bases of professional subject development in future intelligence specialists in the system of postgraduate education]. Vijs kova osvita, 21, 3-12.

7. Leont ev, V. P. (2000). Normativnoye obespecheniye fizicheskoy podgotovki kursantov vysshikh voyenno-uchebnykh zavedeniy Sukhoputnykh voysk Ministerstva oborony Ukrainy [Normative support of physical training of cadets of higher military educational institutions of the Land Forces of the Ministry of Defense of Ukraine] (Abctract of PhD thesis). Kyiv, $22 \mathrm{s.}$

8. Oderov, A., Shlyamar, I., Baldecz kyj, A. (2013). Systema perevirky ta otsinyuvannya fizychnoyi pidhotovlenosti viyskovosluzhbovtsiv zbroynykh syl inozemnykh derzhav [System of inspection and assessment of physical fitness of servicemen of the armed forces of foreign states]. Moloda sportyvna nauka Ukrayiny, 17(2), 109-113.

9. Osodlo, V. I. (2013). Psyxologichni zasady profesijnogo stanovlennya sub'yekta vijs `kovoprofesijnoyi diyal'nosti [Psychological principles of professional development of the subject of military-professional activity] (Doctoral dissertation). Kyiv, 554.

10. Romanchuk, S., Romanchuk, V. (2010). Fizychna pidhotovka v sukhoputnykh viyskakh zbroynykh syl providnykh derzhav NATO [Physical training in the ground forces of the armed forces of the leading NATO states]. Moloda sporty vna nauka Ukrayiny. 14(2), 302-306.

11. Syromyatnikov, I. V. (2007). Professional'naya sub"yektnost' ofitsera: sushchnost', struktura i tipologicheskiye proyavleniya [Professional subjectivity of an officer: essence, structure and typological manifestations]. Vestnyk Voennogo universiteta. 2(10), 50-58.

12. Brushlynskyi, A. V. (2013). Chelovek, sub"yekt, lichnost' v sovremennoy psikhologii [Man, subject, personality in modern psychology]. Moskva, 1, 584.

13. Pro zatverdzhennya Tymchasova nastanova z fizychnoyi pidhotovky u Zbroynykh Sylakh Ukrayiny: nakaz Heneralnoho shtabu Zbroynykh Syl Ukrayiny vid 11.02.2014 r. № 35 [About approval Provisional instruction on physical training in the Armed Forces of Ukraine: the order of the General Staff of the Armed Forces of Ukraine]. Kyiv, 158.

14. Yagupov, V. V. (2015). Profesiynyy rozvytok osobystosti fakhivtsya: ponyattya, zmist ta osoblyvosti [Professional development of the specialist's personality: concept, content and features]. Pedahohichni, psykholohichni nauky ta sotsialna robota, 175, 22-28. Retrieved from http://nbuv.gov.ua/UJRN/NaUKMApp_2015_175_4.

15. Yagupov, V. V. (2008). Sub"ektno-diyalnisnyy pidkhid yak efektyvna metodolohichna osnova formuvannya hotovnosti viyskovoho kerivnyka do upravlinskoyi diyalnosti. [Subjectactivity approach as an effective methodological basis for forming the readiness of a military leader for managerial activity]. Problemy ta perspektyvy formuvannya natsionalnoyi humanitarnotekhnichnoyi elity, 17(21), 101-111.

16. Yagupov, V. V. (2016). Sub"ektnost`y` professy`onal`naya sub"ektnost` pedagoga kak y`ntegral`nyj pokazatel sformy`rovannosty` ego professy`onal`noj kompetentnosty [Subjectivity and professional subjectivity of a teacher as an integral indicator of the formation of his professional competence]. Rozvitok suchasnoí osvíti: teoríya, praktika, ínnovatsíí, Kyiv, Milenium, 324-325.

17. Yagupov, V. V., Kryshtal', N. A., Korol', V. N. (2013). Formirovaniye i razvitiye professional'noy sub"yektnosti ofitserov. [Formation and development of the professional subjectivity of officers]. Izvestiya Rossiyskoy akademii obrazovaniya, 1, 74-83. 
РЕЗЮМЕ

Василий Ягупов, доктор педагогических наук, профессор Национальный университет обороны Украины имени Ивана Черняховского ORCID ID 0000-0002-8956-3170

Сергей Жембровський, кандидат педагогических наук, доцент Национальный университет обороны Украины имени Ивана Черняховского ORCID ID 0000-0003-4903-9398

\section{Перспективные системы диагностирования физической подготовленности военнослужащих вооруженных сил Украины: теоретико-методологическое обоснование}

В статье представлень перспективную систему диагностирования физической подготовленности военнослужащих Вооруженных сил (далее - ВC) Украины, что осуществлено на ведущих идеях, положениях и принщипах субъектно-деятельностного $u$ контекстного методологических подходов к оценке их профессиональной подготовленности как субъектов военно-профессиональной деятельности. Подчеркивается необходимость учета в процессе диагностирования их физической подготовленности требований $\kappa$ должностному назначения каждого военнослужащего как военного профессионала, $а$ также непосредственно учитывать ее контекст - вид и род войск, требования к должности.

Ключевые слова: диагностирование; физическая подготовленность военнослужаших; физическая готовность военнослужаших; субъектно-деятельностный подход; контекстный подход; шкальл.

\section{SUMMARY}

Vasyl Yagypov, doctor of Science in Pedagogy, professor National Defense University of Ukraine named after Ivan Chernyakhoskyi

Serhii Zhembrovskyi candidate of Pedagogical Sciences, associate Professor

National Defense University of Ukraine named after Ivan Chernyakhoskyi

\section{Perspective system of diagnosing of physical training levels of the Armed Forces of Ukraine military men: its theoretical and methodological background}

Introduction. The article describes the perspective system of diagnosing of physical training levels of the Armed Forces of Ukraine military men. The system is based on the key ideas and principles of agent-active and context methodological approaches to the assessment of the military men's qualification as subjects of military-professional activity. It is seen as extremely important to take into account the military men's physical training while assessing their professional qualification, i.e. considering the demands for their appointment to the office. In particular, we should regard their physical training in the context of type and branch of the Armed Forces and the demands for the appointment to the office. The subject of this research is military men's physical training and physical readiness. The scales for its measurement are reviewed as well. 
Purpose. Substantiation of methodological, organizational, methodological, criterion and diagnostic aspects of objective diagnosis of physical fitness of servicemen.

Methods. In the process of scientific research a set of theoretical and empirical research methods was used. Such theoretical methods as the analysis of dissertations, articles, materials of scientific conferences, psychological and pedagogical, methodical, special literature on a research problem are used. From empirical methods used conversations with teachers, students, specialists in the field of physical training and sports. The study was performed at the Educational and Scientific Institute of Physical Culture and Sports and Health Technologies, National Defense University of Ukraine named after Ivan Chernyakhoskyi.

Results. The perspective system of diagnosing the physical fitness of servicemen of the Armed Forces of Ukraine is substantiated, which is based on the leading ideas, provisions and principles of subject-activity and contextual methodological approaches to assessing their professional training as subjects of military-professional activity.

Originality. The necessity of taking into account in the process of diagnosing their physical fitness the requirements for the official appointment of each serviceman as a military professional and the direct context of his military service - the type and kind of troops, the requirements for the position.

Conclusion. The subject of diagnosis is the physical fitness and physical readiness of servicemen who have the appropriate scales.

Key words: diagnosing; military men's physical training; military men's physical readiness; subject-activity approach; context approach; measurement scales. 